\title{
ACTIVITY OF THE GROUP OF ARTISTS "5 + 1" IN CONCEPTUAL ART
}

\section{Zukhra Zaynutdinova}

Lecturer, Department Of Art History And Theory, National Institute Of Art And Design Named After Kamoliddin Behzod Tashkent, Uzbekistan

\section{ABSTRACT}

The article examines the role and significance of the " $5+1$ " group in the development of contemporary art in Uzbekistan in the context of the creativity of the group's artists. The ideas and aesthetics of paintings, installations, video art in the work of individual artists are revealed in detail.

KEYWORDS: - Conceptual art, installation, painting, video art, artist, exhibition, creativity.

\section{INTRODUCTION}

The modern artistic process is rich in stylistic, directional, thematic, expressive elements of depiction. Along with traditional forms of fine art - painting, graphics and sculpture - today, conceptual art occupies a large place in the hearts of artists.

Conceptual art, or conceptualism, is derived from the Latin word conceptus, meaning "idea," "imagination," and is the artistic direction of postmodernism. Conceptualism was formed in Europe and America in the early 1960s and 1970s.

In conceptualism, the concept of a work is more important than its physical expression. The purpose of art is to convey an idea. Conceptual objects can be in the form of images, phrases, text, diagrams, graphics, drafts, photos, audio and video materials. Any object, event, process can serve as an object of art. One of the founders of the direction, the American artist Joseph Koshut, noted that "art is not an object, but the power of ideas." A classic example of conceptualism is the artist's composition "One and Three Chairs" (1965), which consists of a chair, its photo and a dictionary description of the subject.

\section{THE MAIN RESULTS AND FINDINGS}

Conceptual art is not based on emotional perception, but on an intellectual understanding of the composition seen.

Uzbek artists have consistently mastered the secrets of modern art and understand many of its 
CURRENT RESEARCH JOURNAL OF HISTORY 2(12): 06-12, December

2021

DOI: https://doi.org/10.37547/history-crjh-02-12-02

ISSN 2767-472X

(C2021 Master Journals

Crossref do

gil Google

Accepted 06 ${ }^{\text {th }}$ December, 2021 \& Published $11^{\text {th }}$ December, 2021

principles. They are not limited to mastering complex new forms just to experiment or to imitate European artists. Uzbek artists are also trying to find a new way to express their attitude to reality. In the process, their uniqueness becomes even brighter.

Along with the mature artists whose works have been described in the above chapters and who have contributed to the creation of a new poetics of Uzbek painting, a new generation of artists has also contributed to modern art with their creations. Young representatives of artists are implementing their ideological projects in Uzbekistan and abroad, at international exhibitions of contemporary art. A number of them have formed creative groups and established traditional exhibitions. Among such groups of artists, each of which has its own direction, the group " $5+1$ ", which differs in their ideological worldview, plays an important role in the fine arts of Uzbekistan.

The announcement of 2008 as the Year of Youth in the Republic of Uzbekistan has been a stimulus for various events aimed at accelerating the creative potential of the younger generation. The State Program on creating conditions for the identification and development of the first buds of talent of young creative talents in the field of art and culture shows that the work in this area is carried out according to a clear plan.

As part of the announced state program, the Gallery of Fine Arts of Uzbekistan has prepared an exhibition " $5+1$ ", the main idea of which is to allow young artists to express their talents in the current popular art. New trends, forms and materials, which in many ways correspond to the changes in life, reflect the mainstream of world art practice. is the main position of the organizers of the action.

The participants of the exhibition are Diyor Rozikov, Sanjar Jabborov, Nigora
Sharafkhodjaeva, Sherzod Rajamov, Nuriddin Rasulov, graduates of the National Institute of Art and Design named after Kamoliddin Behzod. They are united by the fact that they are employees of the Gallery of Fine Arts of Uzbekistan. However, the main motivating factor for unification in a single exhibition project was the desire of young artists to present themselves in topical art.

It is no coincidence that the band got such a name. The members of the group point out that they have not been bothered about this for a long time. Due to the fact that the creative group consists of 5 artists and one curator-art critic, who rotates each exhibition, the group is called "5 + 1".

Actual art or contemporary art is associated with new technologies and materials, and for several years has been taking its place in the colorful artistic life of the republic (the term actual art was adopted to denote the main direction of secular art; performances, video art, photo art, etc.). At the same time, young artists of Uzbekistan have every opportunity to get acquainted with the development of contemporary art in other countries - for many years the capital has been the venue of the Tashkent Biennale, the participants of which are bright representatives of secular contemporary art.

Until 2008, S. Jabborov was known as the author of creative projects in the form of video art and installations, which are characterized by postmodernist aspects. The first paintings in S. Jabborov's works were created in 2008, but his desire to create valuable bench paintings was clearly demonstrated in 2011 during his participation in the project "Aesthetics of Hedonism: body, food, soul." In the project, he showcased his great paintings, which were able to engage critics and audiences alike. 
CURRENT RESEARCH JOURNAL OF HISTORY 2(12): 06-12, December

2021

DOI: https://doi.org/10.37547/history-crjh-02-12-02

ISSN 2767-472X

(C2021 Master Journals

\section{Crosser do) (81" Google}

Accepted 06 ${ }^{\text {th }}$ December, 2021 \& Published $11^{\text {th }}$ December, 2021

The aesthetics of the artist's paintings differs from the problems of video art and installations created by him. The main character of his workshop works is a single female figure in various ideological and compositional tones. The dynamics and position of these female characters serve as a plastic satire that reflects the artist's own psychological state. Body parts are enlarged, anatomical proportions are distorted - often female figures with long, woody-like legs that do not fit these proportions. The faces of the characters are not clearly drawn, the facial parts and physiognomic features are obscured by dream techniques. Therefore, the paintings have the character of a sketch according to the texture. Such features are also characteristic of the artist's works depicting several undressed women figures created in 2010-2011.

In S. Jabborov's painting "Tana.Farishta" (2010) the figure of a woman sitting side by side without clothes is created in the style of the artist's painting. Neither the face nor the body aspects are almost visible in this play. The image attracts attention not with its anatomical aspects but with its mystical tone.

Despite the fact that the works "NYO" (2010) and "Telo" (2011) are made in the same style, they clearly show the characteristics of the naked body, the perceptible characteristics. The artist is not interested in the expression of emotions, figurative and psychological characteristics are expressed in the works through the state of the body, dynamics and proportions of the figure.

The semantic depth of ideas and thoughts is one of the idiomatic qualities of Diyor Rozikov's projects. His first work at the IV Tashkent International Biennale in 2007 was a creative experiment on the transformation of painting into another space. He creates unique installations in the space full of conceptual ideas and philosophical fantasies from paintings.
D. Rozikov uses both painting and installation resources in his work. In many cases, these two types are transformed into a holistic project that is skillfully combined by the artist. Rozikov also excels in video art. Although the number of works created by the artist to date is not large, this in itself shows that the artist is not simple, trying to express deep philosophical and ethical issues in unusual plastic ways.

Using large-scale canvases, it uses a minimum of color and compositional resources, thereby drawing our attention to the ideological character in the work.

Sherzod Rajamov is one of the most talented young artists on the threshold of modern fine arts in Uzbekistan. The artist's earlier interest in graphics also had a major impact on his later work. His interest in space and objects served as the basis for the creation of installations.

In Nigora Sharafkhodjaeva's art there is a constructiveness of the artist's world, an overestimation of the visual cut. These aspects are reflected in his projects "KUB", "Koprik", "Oyjamol", "Nigoh". The artist enlarges the size of the real object in his projects. In this way, the artist achieves a convincing illusion of detail, attention to the object, the idea of the scale.

A unique member of the group, Nuriddin Rasulov has been involved in the art of wood carving since his youth. When he chose this type of profession, he had no idea about the exciting creative activity that awaited him in the future. After working at the Gallery of Fine Arts and becoming a member of the creative group " $5+$ $1 "$, he rediscovered his talent. Nuriddin set himself the difficult task of making applied decorative art relevant.

The group's first " $5+1$ " exhibition in 2008 featured paintings, sculptures, installations, objects, photo collages, and wood carvings. The 
CURRENT RESEARCH JOURNAL OF HISTORY 2(12): 06-12, December

2021

DOI: https://doi.org/10.37547/history-crjh-02-12-02

ISSN 2767-472X

(C2021 Master Journals

Crossref do

gil Google

Accepted 06 ${ }^{\text {th }}$ December, 2021 \& Published $11^{\text {th }}$ December, 2021

absence of a single accepted theme was the success of the project, which covered a wide range of social, environmental, philosophical, and issues related to man and the meaning of his life.

Diyor Rozikov was concerned about the environmental problems, the energy crisis, the damage caused to our land as a result of uncontrolled use of oil. He used orgalite, cardboard, canvas and a fan for his installation.

Sherzod Rajamov was excited about the psyche loneliness, problems of the human heart. The idea was reflected in a sculptural specimen holding a candle in a foam-covered hand, which was placed in a semi-dark hall.

Nigora Sharafkhodjaeva presented at the exhibition "K.U.B. (Cybernetic Complex Biology)", which transforms simple perceptible structures (events, behaviors) from minimalism into"sensory chaos "(materials-cube-shaped object, photography, collage).

A number of psychological problems are also reflected in the projects of Sanjar Jabborov and Nuriddin Rasulov. In realizing his idea, Sanjar Jabborov transforms the archetype of medieval epigraphic ornaments into pottery filled with poems of Oriental poets written in different languages of the world. With this, the young artist sings not only of our thirst for water, but also of our thirst for knowledge and life. Nuriddin Rasulov realizes the idea of creating a labyrinth of human life with the help of traditional wood carving. It is only important that we find the answer to the question of our choice in the Moment of Truth - to find the right path or to get lost in the complex processes of events.

The next creative exhibition of the group in 2009 was called "Vertical". The name of the exhibition "Vertical" depends on many factors. This word refers to the high and low that exist in the human mind first, that is, Heaven and Earth. Therefore, another task of the exhibitors is to show the similarity of Heaven and Earth. From this thought, we receive confirmation of how strongly our Earth is the Heaven we aspire to, and that heaven can be found on Earth.

The approach of each exhibitor to this topic is unique and unrepeatable, based on their own worldviews and lifestyles. In particular, Sherzod Rajamov through his project "Royob" reflects the path to perfection. The path is so complex that the author reflects it in the form of a staircase as if on a vertical surface on which a person is moving. Sherzod prefers to leave the idea he has embedded in the concept of his project abstract, leaving it to the viewer to find out what is hidden behind it.

Diyor Rozikov realizes his idea through painting and video art. Life is complex, its emergence is associated with the harmonization of earth and sky. Vertical is a movement from top to bottom or vice versa from bottom to top. He uses this rhythm of movement in his project 1303, in which Zina appears as a symbolic representation of thoughts about Man's aspirations and destiny. The artist's second project is called "Verticals," which is manifested by the casting of shades of two fabrics. In this case, the movement of the shadow reflects the speed of time and the transience of life. These two projects are combined in a unique experiment, if in the project "1303" used painting video art, and in the project "Verticals", on the contrary, the fabric favors the video effect.

Sanjar Jabborov's work "Between Heaven and Earth" expresses and glorifies the height of divine love. Installation and video art are so united in this example of creation that it is no exaggeration to compare it to the soul living in the human body. The author's youth, lack of life 
CURRENT RESEARCH JOURNAL OF HISTORY 2(12): 06-12, December

2021

DOI: https://doi.org/10.37547/history-crjh-02-12-02

ISSN 2767-472X

(C2021 Master Journals

Crossref doi

gil Google

Accepted 06 ${ }^{\text {th }}$ December, 2021 \& Published $11^{\text {th }}$ December, 2021

experience, unseen sufferings of love and affection demanded a great deal of responsibility in expressing this process, and it is this sense of responsibility that is one of the main ideas in the play.

Nuriddin Rasulov, unlike other participants of the exhibition, and, of course, remained faithful to his craft, presented an installation called "Endless", which consists of works of applied art. These labor-intensive works of traditional art, while non-standard with modern art, especially the installation, blend in with the author's inner world. Maybe that's why the play makes it possible to understand his philosophy about life and people. In his work, the author shares his thoughts on the speed of life and the eternity of the soul. Its lids are the space that preserves the human soul, while the carved vertical directions reflect the soul's return to heaven, to another dimension.

Nigora Sharafkhodjaeva's approach to this issue was unique. He built a bridge using video cassettes that symbolizes the transition from one dimension to another and the experience of a moment in the process called life. The author's contradictory approach to the vertical theme also confirms his paradoxical view of the universe and the idea that contradiction leads to truth.

The curator of the exhibition was an employee of the Gallery of Fine Arts, art critic Saodat Ruzieva.

Although the five artists mentioned above work in the same environment, there is an expression that is unique to each of their works, which allowed them to further unite in the exhibition space. The exhibition has a soul-stirring, soulstirring breath that allows a person to live in a different dimension and think in a different category, albeit for a few moments. This is the main purpose of any exhibition.

The group's 2010 exhibition, which became a tradition, was led by Gayane Umerova, an art critic at the Fine Arts Gallery. Just as the work of the band members has a unique conceptual style, it is also worth noting that each exhibition is named. This time the exhibition was called "SENSUS". The Sensus exhibition project, in its essence, is one of the areas of understanding of the theory, derived from sensualism, which focuses on its emotional principles: "There is nothing that does not exist in the mind, in the senses." It is well known that art encompasses all five sensory elements used in understanding the external world. The sense organs, such as sight, hearing, taste, smell, and sensation, are the means by which mental conception is created. However, each sense organ contains a secondary factor: the external appearance finds its expression in the inner world, it is the internal perception of these impressions, free from external influences. As a set of sensory categories, an object changes its original visual appearance in the mind.

The objects presented by the artists through installation, video-art and painting determine the main methodological details and typological features of this project. Artists, who follow the secular trends of the information and technological age of art development, combine modern media in their objects using traditional metaphors and achieve a strong visual effect.

This year, another exhibition of the group " $5+1$ " was organized. The project was named "Silentium" in the framework of the "Center of Authority for Cultural Managers" of the Goethe Institutes in Eastern Europe and Central Asia.

"Silentium" is a form of silence, thinking, understanding, that is, silence. How much can be said by keeping silent. The exhibition highlights the trends in contemporary art of our country with its unique poetry, elegance and richness of content. Therefore, the main criterion of the 
CURRENT RESEARCH JOURNAL OF HISTORY 2(12): 06-12, December

2021

DOI: https://doi.org/10.37547/history-crjh-02-12-02

ISSN 2767-472X

(C2021 Master Journals

Crossref do

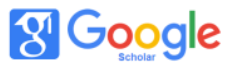

Accepted 06 ${ }^{\text {th }}$ December, 2021 \& Published $11^{\text {th }}$ December, 2021

exhibition is a clear and concise, constructive expression of the content, the creation of works in the style of minimalism.

At the exhibition, Sh. Rajamov decided to combine video art and painting. The hardworking hands depicted in the painting represent reality, some rudeness in life, and the young man sitting upright in the video is depicted in the image of a poet hidden in everyone's heart. The idea of the work is that no matter what kind of work a person does, a special light is hidden in his heart.

The next topic of the group " $5+1$ " is called "Magnet", which aims to show its features in the current art, not by a specific body, but by a comparative analogy.

"Magnet" is its simple concept, its nature. When we say magnet, we mean a metal object that attracts each other. In this exhibition, however, the use of the word magnetic is an involuntary allegory. Allegory is a figurative concept, one of the words that has a meaning that means excerpts.

The name of the exhibition, organized in 2015, is "Spectrum". We know that the spectrum is a system or process that is the sum of all appearances of this or that dimension. The curator of the exhibition is Saodat Ruzieva.

The approach of each exhibitor to this topic is unique and unrepeatable, based on their own worldviews and lifestyles. While in previous exhibitions, artists have created works in the areas of installation and video art of topical art, in this exhibition they are united by the fact that they created in abstract painting.

Nigora Sharafkhodjaeva is not based on the material she uses to create her work, but on the idea she is thinking about today. As a creator, he has tried himself in various areas of topical art to date, and these efforts have not been in vain.
Nigora is participating in the exhibition with a painting based on her color scheme. This work is a rage of his inner feelings, his views on events and happenings in life.

Diyor Rozikov creates his works on a large scale. His works are a collection of these different thoughts and opinions. The works presented in this exhibition are a logical continuation of the previous ones. The author is interested in the role of man in society, issues of development.

Inspired by nature, Nuriddin Rasulov tries to express his feelings through bright colors. Although his works are abstract, they have a very poetic character. He has the ability to enrich it with his imaginary world as he observes existence. For this reason, the artist strives to express every scene he sees without the use of paints in clear forms.

Sanjar Jabborov - the artist is interested in unstable situations, complex characters. She reflects balance in a unique way and skillfully portrays aspects of woman and her nature in her works as a careful observer.

\section{Conclusion}

Another aspect of this year's exhibition is that the exhibition features more paintings by members of the group.

When we look at the work of young artists, we see that their worldviews, styles and materials of depiction, as well as their ideological goals are changing. At the beginning of their work, they were interested in ecological and social issues, but from year to year their work shows that they are led by aesthetic views.

\section{ReFERENCES}

1. Xakimov A.A. New Uzbek painting. $-\mathrm{T}$.: 
CURRENT RESEARCH JOURNAL OF HISTORY 2(12): 06-12, December

2021

DOI: https://doi.org/10.37547/history-crjh-02-12-02

ISSN 2767-472X

(C)2021 Master Journals

\section{Crossref doi gi Google}

Accepted 06 ${ }^{\text {th }}$ December, 2021 \& Published 11 th December, 2021

“SAN'AT" publishing house, 2014. -183 p.

2. Akhmedova N.R. Jivopis Tsentralnoy Azii XX century: traditions, samobytnost, dialogue. $-\mathrm{T}$ .: SDS, 2004. -224 p.

3. Taktash R.X. Izobrazitelnoe art of Uzbekistan (secondary)

4. polovina X1X veka do 60-e gg. XX century). Tashkent .: 1972.

5. Ahmedova N. Period and artist. - Art, 2001, issue 3.

6. Xakimov A.A. Blue peacocks.- yellow peacock: squirrels in the 1990s painting. Art, 1999/1 issue.

7. Xakimov A.A. Art of new Uzbekistan. - Art, $1999 / 2$ issues.

8. Khakimov AA 1920-1980 Art of Uzbekistan. Art 1999/4 issues.

9. 8.Рашидов, Ж. Х. У. (2020). СОВРЕМЕННЫЕ ПРОБЛЕМЫ И ТЕНДЕНЦИИ РАЗВИТИЯ КНИЖНОГО ДИЗАЙНА. Вестник науки и образования, (24-1 (102)).

10. 9.Рашидов, Ж. Х. У. (2020). Способы интерпретации художественной литературы в книжной графике. Проблемы современной науки и образования, (2 (147)).

11. 10.Utanova, U. A. (2021). THE ROLE OF MUSEUMS IN THE DEVELOPMENT OF TOURISM. CURRENT RESEARCH JOURNAL OF HISTORY (2767-472X), 2(10), 27-32.

12. 11.Utanova, U. A. (2020). FOLK CULTURE IS A SOCIO-HISTORICAL PHENOMENON. International Engineering Journal For Research \& Development, 5(9), 5-5.

13. 12.Курбанова, Д. А. (2015). Об истории прикладного искусства Узбекистана XIX столетия и о предметах Государственного музея искусства народов Востока
Российской Федерации. Молодой ученый, (10), 1513-1515. 